\title{
ANALISIS PENGARUH UKURAN PERUSAHAAN DAN FINANCIAL DISTRESS TERHADAP PENERIMAAN OPINI AUDIT GOING CONCERN
}

\author{
(Studi Empiris Perusahaan Manufaktur di BEI) \\ Imam Aji Santoso ${ }^{1}$, Mardiana ${ }^{2}$, Ageng Setiani Rafika ${ }^{3}$ \\ Dosen Akuntansi Universitas Raharja ${ }^{1}$, Dosen Akuntansi Universitas Raharja ${ }^{2}$, Dosen Sistem \\ Komputer Universitas Raharja ${ }^{3}$ \\ Jl. Jend. Sudirman No. 40, Modern Cikokol, Tangerang \\ imam.aji@raharja.info ${ }^{1}$, mardiana@raharja.info ${ }^{2}$, agengsetianirafika@raharja.info ${ }^{3}$
}

\begin{abstract}
ABSTRAK
Auditor bertugas untuk menilai kewajaran yang ada pada laporan keuangan perusahaan. Dan ada manfaat lain yang didapat selain laporan keuangan, yaitu para user (pengguna) dapat mengetahui informasi internal perusahaan, seperti kemampuan perusahaan dalam menjaga dan mempertahankan kelangsungan usahanya melalui opini audit going concern. Tujuan penelitian ini untuk mengetahui pengaruh ukuran perusahaan dan financial distress terhadap opini audit going concern. Obyek penelitian ini adalah perusahaan manufaktur yang terdaftar di Bursa Efek Indonesia (BEI) dari tahun 2017-2019 sebagai populasi. Pemilihan sampel data ditentukan dengan menggunakan metode cluster sampling sehingga terdapat 36 perusahaan manufaktur sebagai sampel penelitian. Pengujian hipotesis dalam penelitian ini menggunakan analisis regresi logistik dengan program SPSS versi 25 dan tingkat signifikansi sebesar 5\%. Hasil penelitian ini menunjukkan bahwa ukuran perusahaan tidak berpengaruh signifikan terhadap penerimaan opini audit going concern dan financial distress berpengaruh signifikan terhadap penerimaan opini audit going concern.
\end{abstract}

Kata kunci: ukuran perusahaan, financial distress, dan opini audit going concern.

\section{PENDAHULUAN}

Kelangsungan hidup usaha suatu perusahaan adalah situasi atau kondisi yang dialami perusahaan selama jangka waktu yang lama untuk mampu bertahan hidup, dan hal ini sangat penting bagi para investor. Laporan keuangan adalah bagian penting dari perusahaan yang menyediakan informasi keuangan kepada pengguna. Pengguna laporan keuangan akan mempertimbangkan suatu perusahaan dalam menjaga going concern yang dapat diketahui dari kondisi keuangan yang telah dijabarkan secara jelas pada laporan keuangan perusahaan (Yuliyani dan Erawati, 2017). Menurut Ikatan Akuntan Indonesia (2015) laporan keuangan berisi informasi-informasi terkait kinerja keuangan yang berguna sebagai bahan pertimbangan untuk membuat keputusan. Menurut SA 570 (2013) opini audit going concern adalah opini yang menekankan adanya ketidakpastian signifikan mengenai suatu keadaan atau kondisi yang dapat 
menimbulkan keraguan yang secara potensial mampu mempengaruhi kemampuan entitas dalam menjalankan kelangsungan usaha.

Dalam case ini, demi mempertahankan kelangsungan hidup usaha suatu perusahaan tergantung dari ukuran perusahaan, financial distress, demi mendapatkan opini audit going concern dari auditor KAP, saat melakukan audit.

\section{PERUMUSAN MASALAH}

Berdasarkan latar belakang yang sudah dijabarkan sebelumnya, maka rumusan masalah pada penelitian ini adalah :

a. Apakah ukuran perusahaan berpengaruh terhadap penerimaan opini audit going concern?

b. Apakah financial distress berpengaruh terhadap penerimaan opini audit going concern?

c.

\section{PEMBATASAN MASALAH}

Agar pembahasan tidak menyimpang dari penelitian yang dilakukan, maka peneliti membatasi masalah yang akan dibahas, yang meliputi populasi yang digunakan adalah laporan keuangan perusahaan manufaktur yang terdaftar di BEI pada tahun 2017-2019

\section{HASIL PENELITIAN SEBELUMNYA}

\begin{tabular}{|c|c|c|c|c|}
\hline No. & $\begin{array}{l}\text { Nama Peneliti dan tahun } \\
\text { penelitian }\end{array}$ & Sampel dan tools penelitian & Variabel & Kesimpulan \\
\hline 1. & $\begin{array}{l}\text { Pipin Kurnia dan Nanda } \\
\text { Fito Mella (2018) }\end{array}$ & $\begin{array}{l}\text { - Perusahaan Manufaktur } \\
\text { tahun 2010-2015 sebanyak } \\
37 \text { sampel pada BEI } \\
\text { - Analisis regresi Logistic }\end{array}$ & $\begin{array}{c}\text { Kualitas audit } \\
\text { Financial Distress } \\
\text { Audit tunure } \\
\text { Ukuran perusahaan }\end{array}$ & $\begin{array}{l}\text { Tidak signifikan } \\
\text { Signifikan positif } \\
\text { Tidak signifikan } \\
\text { Tidak signifikan }\end{array}$ \\
\hline 2. & $\begin{array}{l}\text { Dea Izazi dan Rizka Indri } \\
\text { Arfianti (2019) }\end{array}$ & $\begin{array}{l}\text { - Perusahaan non keuangan } \\
\text { tahun 2014- } 2016 \text { sebanyak } \\
108 \text { sampel pada BEI } \\
\text { - Analisis regresi logistik }\end{array}$ & $\begin{array}{l}\text { Debt default } \\
\text { Financial Distress } \\
\text { Audit tunure } \\
\text { Opinion Shoping }\end{array}$ & $\begin{array}{l}\text { Signifikan positif } \\
\text { Signifikan positif } \\
\text { Tidak signifikan } \\
\text { Tidak signifikan }\end{array}$ \\
\hline 3. & $\begin{array}{l}\text { Abdul Gani Damanhuri } \\
\text { dan I made Pande } \\
\text { Dwzziana Putra (2020) }\end{array}$ & $\begin{array}{l}\text { - Perusahaan manufaktur } \\
\text { yang terdaftar di BEI 2015- } \\
2018 \text { sebanyak } 92 \text { sampel. } \\
\text { - Analisis regresi logistik }\end{array}$ & $\begin{array}{l}\text { Financial distress } \\
\text { Total aset turnover }\end{array}$ & $\begin{array}{l}\text { Signifikan positif } \\
\text { Signifikan negatif }\end{array}$ \\
\hline
\end{tabular}


ISSN: 2723-5262

Online ISSN: 2723-5270

\begin{tabular}{|c|c|c|c|c|}
\hline & & & Audit tunure & Signifikan negatif \\
\hline 4. & $\begin{array}{l}\text { Torbjorn Tagesson dan } \\
\text { Peter Ohman (2015) }\end{array}$ & $\begin{array}{l}\text { - Data empiris didasarkan } \\
\text { pada laporan tahunan dan } \\
\text { laporan audit } 2.547 \\
\text { Perusahaan yang bangkrut } \\
\text { pada tahun } 2010 \text { setelah } \\
\text { krisis keuangan di Swedia } \\
\text { - Analisis Regresi Logistik }\end{array}$ & $\begin{array}{l}\text { Audit Firm } \\
\text { Financial distress } \\
\text { The date audit } \\
\text { Audit fee }\end{array}$ & $\begin{array}{r}\text { Signifikan positif } \\
\text { Signifikan positif } \\
\text { Signifikan negatif } \\
\text { Signifikan positif }\end{array}$ \\
\hline 5. & $\begin{array}{l}\text { José Luis Gallizo, Ramon } \\
\text { Saladrigues (2016) }\end{array}$ & $\begin{array}{l}\text { - Sebanyak } 48 \text { perusahaan di } \\
\text { Spanyol } \\
\text { - Analisis regresi Logistic }\end{array}$ & $\begin{array}{c}\text { Current ratio } \\
\text { Size } \\
\text { Return on asset }\end{array}$ & $\begin{array}{l}\text { Signifikan negatif } \\
\text { Signifikan negatif } \\
\text { Signifikan negatif }\end{array}$ \\
\hline
\end{tabular}

\section{LANDASAN TEORI}

\section{Teori Signaling/Sinyal}

Teori sinyal dalam hal ini adalah sebuah upaya yang dilakukan oleh manajemen untuk memberikan sinyal informasi terkait perkembangan perusahaan kepada investor (Brigham dan Houston, 2014) Teori sinyal memiliki kegunaan dalam meminimalisir asimetris informasi antara manajemen perusahaan dan pemilik perusahaan. Agen selaku manajemen yang mengelola perusahaan berkewajiban untuk memberikan sinyal kepada prinsipal melalui laporan keuangan

\section{Teori Agensi}

Teori keagenan adalah pendesainan kontrak agar memberikan dukungan untuk agen supaya melakukan sebuah tindakan rasional yang memprioritaskan 22 kebutuhan prinsipal, ketika kepentingan agen bertolak belakang dengan kepentingan prinsipal maka dalam hal ini baik investor dana agen harus melakukan penyesuaian kepentingannya untuk mengatasi masalah keagenan (Scott, 2015).

\section{HIPOTESIS}

\section{Pengaruh Ukuran Perusahaan terhadap Penerimaan Opini Audit Going Concern}

Ukuran perusahaan merupakan sesuatu yang digunakan untuk mengetahui kekuatan keuangan perusahaan yang dapat nilai dengan berbagai proksi antara lain dengan jumlah penjualan, jumlah keseluruhan aset, ataupun nilai kapitalisasi pasar. Ukuran perusahaan diukur melalui nilai jumlah keseluruhan aset menunjukan nilai Financial Distress (X2), Opini Audit Going Concern (Y) Ukuran Perusahan (X1) 40 yang tidak mudah berubah (stabil) bila dibandingkan dengan jumlah penjualan atau kapitalisasi pasar. Perusahaan yang memiliki jumlah keseluruhan aset yang besar maka akan menciptakan arus kas masuk yang positif sehingga perusahaan dapat menjalankan kelangsungan usahanya dalam jangka waktu yang relatif lama 
(Rakatenda dan Putra, 2016). Sebagai bahan pertimbangan auditor dalam menerbitkan sebuah opini, bila suatu entitas memiliki total aset yang besar maka akan sedikit peluang untuk penerimaan opini audit going concern jika dibanding dengan perusahaan dengan perusahaan yang jumlah asetnya sedikit. Perusahaan besar memiliki manajemen yang lebih baik dalam mengelola perusahaan, terutama dalam hal pengelolaan keuangan dan kondisi keuangan yang lebih baik. . Penelitian dilakukan oleh Ramadhanty dan Rahayu (2015) menemukan bukti adanya pengaruh dengan arah positif antara ukuran perusahaan terhadap kemungkinan mendapat opini audit going concern. Selanjutnya, menurut hasil pengamatan dari Rakatenda dan Putra (2016), Gallizo dan Saladrigues (2016), Gama dan Astuti (2014) berhasil membuktikan pengaruh dengan arah negatif yang timbul antara ukuran perusahaan pada kemungkinan mendapatkan opini going concern.

H1 : Ukuran Perusahaan berpengaruh terhadap penerimaan opini audit going concern

\section{Pengaruh Financial Distress terhadap Penerimaan Opini Audit Going Concern}

Financial distress merupakan suatu kondisi perusahaan yang sedang dalam masa kesukaran keuangan sehingga terdapat keraguan yang signifikan dalam 41 mempertahankan kelangsungan usaha suatu perusahaan. Kesukaran keuangan memberikan indikasi bahwa kondisi keuangan yang dialami perusahaan dalam kondisi yang tidak sehat (Yuliyani dan Erawati, 2017). Perusahaan yang sudah diprediksi memiliki resiko kebangkrutan maka keberlangsungan hidup perusahaan pada kurun waktu yang singkat maupun panjang akan diragukan. Berdasarkan pembuktian pengamatan yang dilakukan oleh (Ulya, 2012) hasilnya menunjukan financial distress tidak ada pengaruh untuk kemungkinan menerima opini audit going concern. Menurut hasil pengamatan yang dilakukan oleh Ramadhanty dan Rahayu (2015) berhasil membuktikan bahwa kesulitan keuangan memiliki pengaruh dengan arah negatif terhadap kemungkinan penerimaaan opini audit going concern.

$\mathrm{H} 2$ : Financial distress berpengaruh terhadap opini audit going concern

Berdasarkan hipotesis diatas, maka kerangka penelitian dapat digambarkan sebagai berikut:

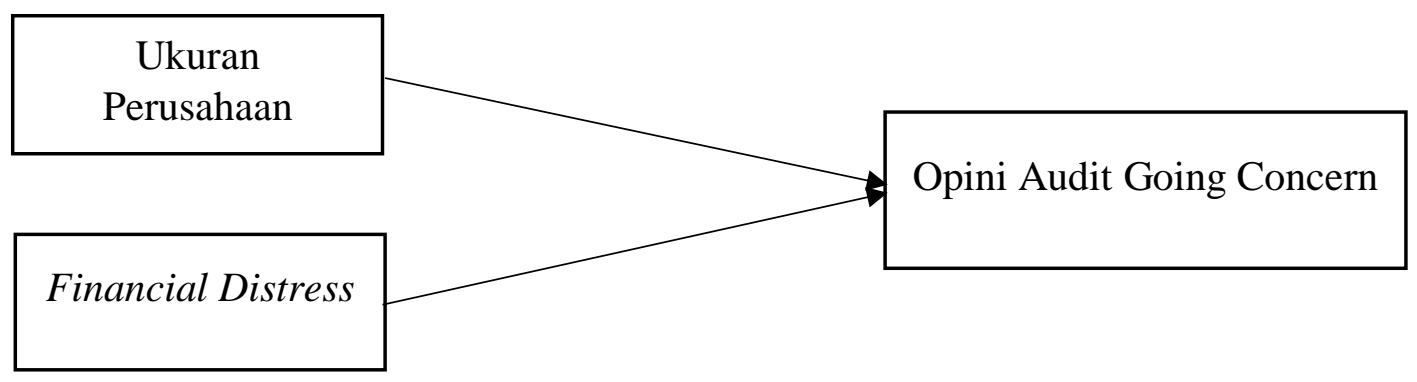




\section{METODE PENELITIAN}

Penelitian ini merupakan jenis penelitian kausal komparatif (causal comparative research). Penelitian kausal komparatif adalah penelitian yang bertujuan untuk menyelidiki hubungan sebab-akibat berdasarkan pengamatan terhadap akibat yang terjadi dan mencari faktor yang menjadi penyebab melalui data-data yang telah dikumpulkan (Yusuf, 2016). Penelitian ini dilakukan pada Bursa Efek Indonesia (BEI) dengan melakukan akses pada situs www.idx.co.id. Dengan populasi perusahaan manufaktur yang terdaftar di Bursa Efek Indonesia periode 20172019.

\section{Definisi Operasional Variabel (Y)}

Opini audit going concern yang dijabarkan dalam SA 570 paragraf 18 merupakan opini yang menekan ketidakpastian material yang terkait dengan kondisi utama ataupun sebuah persitiwa yang secara signifikan menimbulkan sebuah kergauan yang dapat mempengaruhi sebuah entitas dalam mempertahankan kelangsungan usahanya.

Pengukuran untuk opini audit going concern menggunakan variable dummy dengan tujuan untuk menilai opini going concern dan skala nominal yang digunakan pada penelitian ini. Kode 1 dierikan untuk perusahaan yang menerima opini audit going concern, dan untuk kode 0 , diberikan untuk sebaliknya dari kode 1

\section{2.. Definisi Operasional Variabel Independen $(\mathrm{X})$}

\section{a. Ukuran Perusahaan}

Ukuran perusahaan dapat dijabarkan sebagai suatu ukuran yang memberikan informasi mengenai kondisi keuangan baik dari segi aset, penjualan, maupun pada nilai kapitalisasi pasar. Bilamana suatu perusahaan mempunyai aset yang jumlahnya besar maka menggambarkan arus kas yang positif sehingga prospek usaha dalam jangka panjang dapat terjaga (Rakatenda dan Putra, 2016)

Pengukuran yang digunakan untuk ukuran perusahaan sendiri menggunakan ukuran dari total aset, yang kemudian di convert menjadi nilai Logaritma natural (Ln) dari jumlah aset (Minerva dkk., 2020)

$$
\text { Ukuran Perusahaan }=\text { Ln(Total Aset })
$$

\section{b. Financial Distress}

Kesulitan keuangan merupakan suatu keadaan dimana perusahaan dari segi finansial tidak dikatakan sehat sehingga memberikan kemungkinan yang besar perusahaan tersebut mengalami risiko gagal bayar ataupun menimbulkan risiko kebangkrutan yang tinggi (Yuliyani dan Erawati, 2017). Peneliti menggunakan model altman z-score revised sebagai salah satu alat ukur financial distress. 
Pengukuran yang digunakan untuk financial distress, menggunakan model altmal ZScore Revised yang dapat dirincikan sebagai berikut :

$$
Z^{\prime}=0.717 \mathrm{Z} 1+0.847 \mathrm{Z} 2+3.107 \mathrm{Z} 3+0.420 \mathrm{Z} 4+0.998 \mathrm{Z} 5
$$

Keterangan :

$$
\begin{aligned}
& \mathrm{Z} 1=\text { Working capital/total asset } \\
& \mathrm{Z} 2=\text { Retained } \text { earning/total asset } \\
& \mathrm{Z} 3=\text { Earning before interest } \text { and taxes/total asset } \\
& \mathrm{Z} 4=\text { Book value of equity/book value of debt } \\
& \mathrm{Z} 5=\text { Sales/total asset }
\end{aligned}
$$

Peridiksi dihasilkan oleh nilai Z-Score (overall index) akan dikelompokan menjadi tiga ketagori sebagai berikut : keuangan.

1. Apabila nilai Z-Score > 2,90 maka perusahaan dalam keadaan tidak kesulitan

2. Apabila nilai $1,23<\mathrm{Z}$-Score $<2,90$ maka suatu perusahaah masuk kedalam zona abuabu atau grey area yakni suatu kondisi yang bisa dikatakan bahwa perusahaan sedang mengalami kesulitan keuangan atau bisa juga tidak termasuk pada kategori kesulitan keuangan.

3. Apabila nilai Z-Score $<1,23$ maka perusahaan sedang mengalami kesukaran keuangan.

\section{POPULASI DAN SAMPEL}

\section{Populasi}

Populasi dapat dijabarkan sebagai lingkungan umum yang didalamnya terdapat kumpulan keseluruhan objek atau subjek yang memiliki kriteria tertentu sehingga dapat dipelajari untuk ditarik kesimpulan penelitiannya (Sugiyono, 2017 hlm.80). Populasi dalam penelitian ini menggunakan data laporan keuangan yang berada di BEI, dengan konsentrasi pada perusahaan manufaktur dan laporan keuangan tahun 2017-2019

\section{Sampel}

Sampel merupakan suatu anggota yang berasal dari karakteristik maupun jumlah yang dimiliki oleh populasi tersebut (Sugiyono, $2017 \mathrm{hlm} .81$ ). Dalam pengambilan sampel 
dibutuhkan teknik sampling, penelitian ini menggunakan teknik rumusan slovin dalam menentukan jumlah atau banyaknya sampel yang digunakan. Dan berikut rumusan slovin:

$$
\mathrm{n}=\frac{N}{1+N(e) 2}
$$

Keterangan :

$$
\begin{aligned}
& \mathrm{n}=\text { Jumlah Sampel } \\
& \mathrm{N}=\text { Jumlah Populasi } \\
& \mathrm{e}=\text { Erorr Tolarance }
\end{aligned}
$$

\section{HASIL DAN PEMBAHASAN}

Statistik deskriptif disajikan untuk memberikan informasi mengenai karakteristik variabelvariabel penelitian khususnya mengenai rata-rata (mean), standar deviasi (standar deviation), nilai maksimum dan nilai minimum. Pada tabel di bawah ini disajikan hasil pengujian statistik deskriptif mengenai variable ukuran perusahaan, financial distress, dan opini audit going concern.

Tabel Hasil Stastistik Deskriptif

\begin{tabular}{llllll}
\hline & $\mathrm{N}$ & Minimum & Maximum & Mean & $\begin{array}{l}\text { Std. } \\
\text { Deviation }\end{array}$ \\
\hline Ukuran Perusahaan & 108 & 22,24734 & 32,20096 & 28,0633974 & 1,85724548 \\
\hline Financial Distress & 108 & $-10,80$ & 6,60 &, 6285 & 2,82746 \\
\hline $\begin{array}{l}\text { Opini Audit Going } \\
\text { Concern }\end{array}$ & 108 & 0 & 1 &, 42 &, 495 \\
\hline Valid N (listwise) & 108 & & & & \\
\hline
\end{tabular}

Sumber : Output SPSS Data diolah peneliti (2021)

Tabel diatas menunjukan hasil statistik deskriptif dari tiap-tiap variabel penelitian, hasil statisktik deskriptif variabel ukuran perusahaan menunjukan bahwa nilai minimum dari ukuran perusahaan sebesar 22,24734 dan nilai maksimum untuk ukuran perusahaan sebesar 32,20096 untuk nilai mean diperoleh hasil sebesar 28,0633974 untuk perolehan nilai standar deviasi sebesar 1.85724548. Hasil statistik deskriptif varibel financial distress menunjukan bahwa untuk perolehan nilai minimum ialah -10.80 , nilai maksimum ialah sebesar 6,60 untuk perolehan nilai mean sejumlah 0,6285 dan standar deviasi diperoleh hasil sebesar 2,82746. Hasil statistik deskriptif menunjukan bahwa opini audit going concern memiliki nilai maksimum sebesar 1 dan 
nilai minimum sebesar 0 , untuk nilai mean diperoleh hasil sebesar 0,42 dan standar deviasi sebesar 0,495. Perolehan dari nilai rata-rata lebih kecil dari standar deviasi yakni 0,42

\section{Hasil Uji Fit 1}

\begin{tabular}{llll}
\hline Iteration & & -2 Log likelihood & Coefficients Constant \\
\hline Step 0 & 1 & 146,706 &,- 333 \\
\hline & 2 & 146,706 &,- 336 \\
\hline & 3 & 146,706 &,- 336 \\
\hline
\end{tabular}

Sumber : Output SPSS Data diolah peneliti (2021)

\section{Hasil Uji Fit 2}

\begin{tabular}{llllll}
\hline Iteration & $\begin{array}{l}-2 \text { Log } \\
\text { likelihood }\end{array}$ & Constant & $\begin{array}{l}\text { Ukuran } \\
\text { Perusahaan }\end{array}$ & $\begin{array}{l}\text { Financial } \\
\text { Distress }\end{array}$ \\
\hline Step 1 & 1 & 96,418 & 5,384 &,- 205 &,- 361 \\
\cline { 2 - 6 } & 2 & 81,717 & 5,501 &,- 206 &,- 747 \\
\cline { 2 - 6 } & 3 & 75,766 & 5,003 &,- 178 & $-1,182$ \\
\cline { 2 - 6 } & 4 & 74,648 & 4,882 &,- 166 & $-1,472$ \\
\cline { 2 - 6 } & 5 & 74,606 & 4,867 &,- 163 & $-1,543$ \\
\cline { 2 - 6 } & 6 & 74,606 & 4,866 &,- 163 & $-1,546$ \\
\hline
\end{tabular}

Sumber : Output SPSS Data diolah peneliti (2021)

Berdasarkan hasil output tersebut maka terjadi penurunan nilai yang semula 146,706 menjadi 74,606 yakni terjadi penurunan sebesar 72,100. .Hal ini menunjukan bahwa setelah variabel bebas tersebut dimasukan dalam model regresi maka bisa memperbaiki model fit sehingga membuktikan jika model regresi yang baik.

Hasil Uji Hosmer and Lomeshow's Goodness of Fit Test

\begin{tabular}{llll}
\hline Step & Chi-Square & df & Sig. \\
\hline 1 & 3,354 & 8 &, 910 \\
\hline Sumber : Output SPSS Data diolah peneliti $(2021)$ & &
\end{tabular}

Sumber : Output SPSS Data diolah peneliti (2021)

Berdasarkan hasil uji diatas diketahui bahwa nilai signifikan 0,910 yang nilainya besar dari 0,05 sehingga hipotesis nol diterima, yang berarti tidak ada perbedaan antara klasifikasi yang diprediksi dengan klasifikasi yang diamati. Sehingga dapat disimpulkan bahwa pada model regresi logistik yang digunakan telah memenuhi kecukupan data (fit). 


\begin{tabular}{llllllll}
\hline & & B & S.E & Wald & df & Sig. & Exp (B) \\
\hline Step 1 $1^{\mathrm{a}}$ & $\begin{array}{l}\text { Ukuran } \\
\text { Perusahaan }\end{array}$ &,- 163 &, 173 & 0,891 & 1 &, 345 &, 850 \\
\cline { 2 - 8 } & $\begin{array}{l}\text { Financial } \\
\text { Distress }\end{array}$ & $-1,546$ &, 367 & 17,749 & 1 &, 000 &, 213 \\
\hline \multicolumn{2}{c}{ Constant 4,866} & 4,814 & 1,022 & 1 &, 312 & 129,820 \\
\hline
\end{tabular}

Sumber : Output SPSS Data diolah peneliti (2021)

Hasil tersebut menunjukan bahwa nilai sebesar 0,345 >0,05, maka berarti bahwa hipotesis pertama (H1) dalam penelitian ini ditolak, artinya dapat disimpulkan bahwa ukuran perusahaan tidak memiliki pengaruh signifikan terhadap penerimaan opini audit going concern.

Hasil tersebut menunjukan bahwa nilai sebesar $0,000<0,05$, maka berarti bahwa hipotesis kedua $(\mathrm{H} 2)$ dalam penelitian ini diterima sehingga dapat disimpulkan bahwa financial distress memiliki pengaruh signifikan terhadap penerimaan opini audit going concern

\section{KETERBATASAN PENELITIAN}

Keterbatasan penelitian ini terdapat pada variable $\mathrm{x}$, yang menggunakan hanya 2 variabel $\mathrm{x}$ saja, yaitu ukuran perusahaan, financial distress, dan hanya menggunakan perusahaan manufaktur saja.

\section{SIMPULAN}

Berdasarkan hasil penelitian yang diperoleh melalui pengujian statistik serta pembahasan, maka dapat disimpulkan bahwa ukuran perusahaan tidak berpengaruh signifikan terhadap opini audit going concern, dan financial distress berpengaruh signifikan terhadap opini audit going concern. Untuk peneliti selanjutnya diharapkan kedepannya lebih banyak lagi menggunakan variable $\mathrm{x}$. Variabel x yang mungkin digunakan karena berhubungan dengan opini audit going concern, seperti strategi manajemen, audit tunure, dan lainnya

\section{DAFTAR PUSTAKA}

Brigham, E. F., \& Houston, J. F. (2014). Dasar-dasar Manajemen Keuangan (Edisi 11). Salemba empat.

Damanhuri, A. G., \& Putra, I. M. P. D. (2020). Pengaruh Financial Distress, Total Asset Turnover, dan Audit Tenure pada Pemberiaan Opini Audit Going Concern. E-Jurnal Akuntansi Universitas $\quad$ Udayana, 2392-2402. https://doi.org/10.24843/EJA.2020.v30.i09.p17

Gallizo, J. L., \& Saladrigues, R. (2016). An analysis of determinants of going concern audit opinion: Evidence from Spain stock exchange. Omnia Science, 12(1), 1-16. https://doi.org/http://dx.doi.org/10.3926/ic.683 
Ikatan Akuntan Indonesia. (2015). Pernyataan Standar Akuntansi Keuangan. Ikatan Akuntan Indonesia

Institut Akuntan Publik Indonesia. (2013). Standar Profesional Akuntan Pubik Indonesia. Salemba Empat

Izazi, D., \& Arfianti, R. I. (2019). Pengaruh Debt Default, Financial Distress, Opinion Shopping Dan Audit Tenure Terhadap Penerimaan Opini Audit Going Concern. Jurnal Akuntansi, 8(1), 1-14. https://doi.org/10.46806/ja.v8i1.573

Kurnia, P., \& Mella, N. F. (2018). Opini Audit Going Concern: Kajian Berdasarkan Kualitas Audit, Kondisi Keuangan, Audit Tenure, Ukuran Perusahaan, Pertumbuhan Perusahaan dan Opini Audit Tahun Sebelumnya pada Perusahaan yang Mengalami Financial Distress pada Perusahaan Manufaktur. Jurnal Riset Akuntansi Dan Keuangan, 6(1), 105-122. http://ejournal.upi.edu/index.php/JRAK/article/view/8937/7437

Minerva, L., Sumeisey, V. S., Stefani, S., Wijaya, S., \& Lim, C. A. (2020). Pengaruh Kualitas Audit, Debt Ratio, Ukuran Perusahaan dan Audit Lag terhadap Opini Audit Going Concern. Owner, 4(1), 254. https://doi.org/10.33395/owner.v4i1.180

Ramadhanty, R., \& Rahayu, S. (2015). Analisis Pengaruh Financial Distress, Strategi Emisi Saham, Size Perusahaan dan Profitabilitas Terhadap Penerimaan Opini Audit Modifikasi Going Concern ( Studi Pada Perusahaan Pertambangan Yang Terdaftar Di Bursa Efek Indonesia Periode 2009-2013 ). E-Proceeding of Management, 2(1), 381-388.

Rakatenda, G. N., \& Putra, I. W. (2016). Opin Audit Going Concern dan Faktor - Faktor yang Mempegaruhinya. E-Jurnal Akuntansi Universitas Udayana, 16(2), 1347-1375.

Scott, W. R. (2015). Financial Acconting Theory. Pearson Prentice Hall.

Sugiyono. (2017). Metode Penelitian Kuantitatif,Kualitatif, dan R \& D. Alfabeta.

Tagesson, T., \& Ohman, P. (2015). To be or Not to be - Auditor's ability to Signal Going Concern Problems. Journal of Accounting \& Organizational Change, 11(2), 175-192. https://doi.org/http://dx.doi.org/10.1108/JAOC-04-2013-0034 Downloaded

Yuliyani, N. M. A., \& Erawati, N. M. A. (2017). Pengaruh Financial Distress, Proftabilitas, Leverage dan Likuiditas Pada Opini Audit Going Concern. E-Jurnal 